\title{
Trombosis Berulang pada Pasien dengan Polisitemia Vera dan Penyakit Ginjal Kronis
}

\author{
Muhammad Firdaus ${ }^{1}$, Irza Wahid ${ }^{2}$
}

\begin{abstract}
Abstrak
Polisitemia vera adalah kelainan mieloproliferatif dimana terjadi abnormalitas klonal yang melibatkan sel progenitor hematopoietik multipoten sehingga sel darah merah normal, granulosit dan trombosit berakumulasi tanpa adanya stimulus fisiologis.Dilaporkan seorang wanita berusia limapuluh delapan tahun dengan keluhan utama kelemahan anggota badan kanan sejak tiga hari sebelum masuk rumah sakit. Bicara pelo, mulut miring ke kanan. Riwayat wajah sering berwarna kemerahan dan telinga berdenging. Terdapat riwayat trombosis berupa bengkak merah, hangat dan nyeri di tungkai kanan satu bulan yang lalu. Pemeriksaan fisik mendapatkan plethora, deviasi lidah ke kanan dan penurunan kekuatan motorik ekstremitas kanan. Pemeriksaan laboratorium menunjukkan peningkatan kadar hemoglobin, hematokrit, eritrosit dan trombosit. Tidak ditemukan hipoksemia, ureum dan kreatinin meningkat dengan tingkat klirens kreatinin menurun dan didapatkan adanya proteinuria pada urinalisis. Pemeriksaan CT-scan otak mendapatkan kesan infark serebri multipel dan atrofi otak. Sonogram kedua ginjal sesuai gambaran penyakit ginjal kronis. Terapi yang seharusnya juga diberikan pada pasien ini adalah dengan hydroxyurea namun terdapat penyulit yaitu penyakit ginjal kronis yang dialami pasien sehingga terapi yang dilakukan pada pasien adalah flebotomi berkala dengan target hematokrit dibawah empat puluh lima persen.
\end{abstract}

Kata kunci: polisitemia vera, trombosis, penyakit ginjal kronis

\begin{abstract}
Polycythemia vera is a myeloproliferative abnormality characterized by clonal abnormality which involving multipotent hematopoietic progenitor cells resulted in the accumulation of normal red blood cell, granulocyte and thrombocyte without proper physiologycal stimulus. It was reported a case of fifty eight years old female presented to our institution with weakness on the right side of limbs since three days prior to hospitalized. Slurred speech, deviated lips to the right. There was history of facial flushings and tinnitus. One month ago, the patient experienced thrombosis symptom with redness and painful swelling on the right lower limb. Physical examination revealed plethora, right deviation of the tongue and decreased motoric strength of the right limbs. Laboratory evaluation shown marked increase of hemoglobin, hematocrite, erythrocyte and thrombocyte. There was no hypoxemia. Ureum and creatinine level was increased and the creatinine clearance decreased with proteinuria presented on urinalysis. Brain CT-scan shown multiple cerebral infarct with brain atrophy. Kidney sonogram consistent with chronic kidney disease. The patient should've been treated with hydroxyurea but contraindicated due to co-morbidity of chronic kidney disease, so this patient was treated by repeated phlebotomy until the hematocrite lower than fourty-five percent.
\end{abstract}

Keywords: polycythemia vera, thrombosis, chronic kidney disease

Affiliasi penulis: 1. Rumah Sakit Islam Ibnu Sina, Pekanbaru. 2.

Bagian IImu Penyakit Dalam, Fakultas Kedokteran Univesitas Andalas, Padang, Indonesia.

Korespondensi: M. Firdaus, Email: pibipd@yahoo.com /

m.firdaus.jk@gmail.com Telp: 0751-37771

\section{PENDAHULUAN}

Polisitemia vera (PV) merupakan kelainan mieloproliferatif dimana terjadi klon abnormal pada aktivitas hematopoietik sel induk dengan peningkatan sensitifitas terhadap growth factor yang mengakibatkan terjadinya peningkatan berbagai sel di 
dalam darah. PV sering ditemukan pada pasien berusia 40-60 tahun dengan rasio pria : wanita 2:1. Insidensi PV sebesar 2,3 kasus per 100.000 populasi tiap tahun. ${ }^{1}$

Etiologi PV masih belum diketahui secara jelas, didapatkan abnormalitas kromosom 20q, trisomi 8 dan $9 p$ pada $30 \%$ pasien $\mathrm{PV}$, namun tidak didapatkan abnormalitas sitogenik yang berhubungan dengan kelainan ini. Diketahui mutasi pada tirosin kinase JAK2 (Janus Kinase 2) dimana terjadi pertukaran asam amino valin dengan fenilalanin (V617F) yang berakibat hilangnya kemampuan auto-inhibisi memiliki peran penting dalam proses terjadinya PV. Mutasi JAK 2 mengakibatkan kemampuan transmisi sinyal dari reseptor eritropoietin (EPO), reseptor trombopoietin (TPO) dan reseptor stimulan faktor koloni granulosit (G-CSF) pada sel hematopoietik menjadi lebih efisien. ${ }^{2}$

Aktivasi JAK2 dapat menjelaskan adanya pembentukan koloni eritroid yang independen terhadap eritropoietin, disamping hipersensitifitas sel progenitor eritroid terhadap eritropoietin dan faktor pertumbuhan hematopoietik lain, resistensinya terhadap apoptosis, diferensiasi terminalnya yang cepat serta peningkatan ekspresi $B C L-X_{1}$ yang seluruhnya merupakan karakteristik PV. Ditemukannya mutasi JAK2 merupakan eksklusi dari eritrositosis reaktif namun bukan merupakan pemeriksaan diagnostik untuk menegakkan $\mathrm{PV} .^{3}$

Trombosis pada PV berawal dari mutasi JAK2 yang mengakibatkan keterlibatan berbagai faktor seperti sel darah merah kualitatif dan kuantitatif, trombosit serta abnormalitas leukosit. Tekanan yang tinggi terhadap dinding pembuluh darah akibat hiperviskositas berpengaruh terhadap disfungsi endotel kronis dan aktivasi leukosit. ${ }^{4}$ Peningkatan resiko trombosis terjadi karena meningkatnya hematokrit yang paralel dengan peningkatan viskositas darah. ${ }^{5}$

Penyakit Ginjal Kronik (PGK) umumnya akan menyebabkan anemia lewat penurunan produksi eritropoietin oleh ginjal. Anemia mulai terjadi pada PGK stage 3 dan akan dialami oleh hampir seluruh pasien yang berada pada stage 4 . Hal ini mendasari pemberian erythropoietin stimulating agents dalam penanganan anemia pada PGK. ${ }^{6}$ Kami melaporkan kasus PV pada pasien dengan PGK. Kejadian PV yang menyertai PGK jarang ditemukan, dimana hanya sebanyak 10 kasus yang pernah dilaporkan. ${ }^{7}$

\section{KASUS}

Seorang wanita 58 tahun datang dengan keluhan lemah pada anggota badan sebelah kanan dan berbicara pelo sejak tiga hari yang lalu. Riwayat wajah sering kemerahan, telinga berdenging serta rasa gatal hilang-timbul yang terutama dirasakan setelah mandi dengan air hangat. Tidak didapatkan riwayat nyeri kepala, nyeri dada, gangguan penglihatan dan perdarahan. Pasien memiliki riwayat stroke 5 tahun yang lalu, diabetes dan hipertensi yang tak terkontrol sejak 5 tahun yang lalu. Bengkak mendadak disertai nyeri dan kemerahan pada tungkai kanan dialami 1 bulan yang lalu, saat itu kadar $\mathrm{Hb}$ $20 \mathrm{~g} / \mathrm{dL}$ dan telah dilakukan flebotomi.

Pemeriksaan fisik didapatkan keadaan umum sedang, tekanan darah $170 / 90 \mathrm{mmHg}$, nadi $88 /$ menit dengan pulsasi kuat dan pengisian cukup, serta nafas 21 kali/menit. Plethora pada wajah, deviasi lidah ke kanan dan lateralisasi anggota gerak ke kanan. Irama dan batas jantung normal, tidak ditemukan bising jantung. Pemeriksaan paru dalam batasan normal. Hepar dan limpa tak teraba. Pulsasi arteri pada seluruh ekstremitas baik, Penilaian fungsi motorik 000 pada ektremitas kanan atas dan 111 pada ekstremitas kanan bawah. Sensibilitas halus dan kasar pada seluruh ekstremitas baik.

Laboratorium darah didapatkan kadar hemoglobin 20,3 g/dL, hematokrit $64 \%$, laju endap darah $1 \mathrm{~mm}$, jumlah eritrosit $8.130 .000 / \mathrm{mm} 3$, gula darah sewaktu $208 \mathrm{mg} / \mathrm{dl}$, ureum $49 \mathrm{mg} / \mathrm{dL}$ dan kreatinin $2,4 \mathrm{mg} / \mathrm{dL}$. Pada urinalisis protein urin $(+) 2$. PT dan aPTT pasien dalam batas normal (13 dan 39,1 detik) sedangkan kadar laktat dehidrogenase meningkat (727 u/L). Trombosit pada awalnya masih dalam jumlah normal, namun pemeriksaan ulangan selama rawatan didapatkan kadar trombosit yang semakin meningkat hingga mencapai 455.000/. $\mathrm{mm}^{3}$ pada hari 10 rawatan. Rontgen dada dan elektrokardiogram dalam batas normal, CT-scan otak didapatkan adanya lesi hipodens multipel di daerah ganglia basalis sinistra, periventrikel lateralis sinistra 
dan lobus parietalis sinistra dengan kesan atrofi otak dan infark cerebri multipel. USG kedua ginjal mendapatkan gambaran sesuai dengan penyakit ginjal kronik.

Penatalaksanaan pada pasien ini meliputi tirah baring, diet diabetes rendah garam dan rendah protein. Diabetes melitus tipe 2 diterapi dengan insulin aspart subkutan $3 \times 6$ unit dengan dosis koreksi sebelum makan. Diberikan amlodipin $1 \times 5 \mathrm{mg}$ dan candesartan $1 \times 8 \mathrm{mg}$ per oral untuk terapi hipertensi pada pasien. Aspirin dosis rendah dan citicholine diberikan untuk terapi stroke pada pasien.

Flebotomi berkala dengan pembuangan darah 300 cc dilakukan pada pasien ini hingga tercapai target hematokrit $<45 \%$. Dilakukan fisioterapi terapi untuk pemulihan fungsi motorik dan verbal pasien. Pasien kemudian diperbolehkan pulang dan rawat jalan di poliklinik hematologi onkologi medis RS Dr M Djamil Padang.

\section{PEMBAHASAN}

Polisitemia Vera (PV) merupakan kelainan darah dengan gambaran mieloproliferasi (eritrositosis, seringkali leukositosis dan/atau trombositosis) disertai kecenderungan terjadinya trombosis dan transformasi menuju mielofibrosis atau leukemia myeloid akut. ${ }^{8}$ Diagnosis Polisitemia Vera (PV) pada pasien ditegakkan berdasaran anamnesis dimana pasien memiliki keluhan telinga berdenging, wajah kemerahan serta kulit terasa gatal. Selain itu pasien juga memiliki riwayat kadar hemoglobin tinggi dan telah dilakukan flebotomi berulang. Pemeriksaan fisik didapatkan plethora pada wajah namun tidak menemukan adanya hepatomegali atau splenomegali yang bisa ditemukan pada tahap lanjut penyakit ini. Dari anamnesis maupun pemeriksaan fisik tidak ditemukan adanya gangguan paru maupun jantung yang dapat menjadi penyebab lain dari eritrositosis.

Pemeriksaan darah rutin diperoleh hemoglobin $20,3 \mathrm{~g} / \mathrm{dl}$ dengan hematokrit $64 \%$ dan leukositosis. Hitung eritrosit didapatkan 8.130 .000 eritrosit/ $/ \mathrm{mm}^{3}$. Menurut kepustakaan, secara klinis mayoritas PV memang tidak memiliki gejala khas, namun jika ditemukan eritrositosis disertai leukositosis, trombositosis atau keduanya maka diagnosis menjadi semakin jelas. ${ }^{9}$ Konfirmasi PV sebagai penyebab eritrositosis adalah dengan pemeriksaan enzim Janus Kinase 2 (JAK2), namun belum bisa dilakukan karena tidak terdapat sarana pemeriksaan. Diagnosis polisitemia vera pada pasien ini ditegakkan berdasarkan kriteria Polycythemia Vera Study Group yaitu adanya peningkatan sel darah merah, saturasi oksigen $>92 \%$ serta leukositosis. Pada awalnya trombosit pasien berada dibawah batas kriteria, namun dalam rawatan didapatkan nilai hitung trombosit justru semakin meningkat hingga diatas 400.000/mm3 sehingga memenuhi kriteria $\mathrm{A} 1+\mathrm{A} 2$ dengan 2 kategori B. ${ }^{10}$

Pasien ini mengalami hemiparesis dextra yang dapat disebabkan oleh adanya trombosis pada arteri otak. Gangguan bicara dan wajah yang asimetris mengindikasikan kemungkinan nervus VII dan XII sebagai fokus anatomis yang dipengaruhi trombus. Pasien mengalami kesulitan untuk berbicara spontan, berkata tidak sinkron dengan yang ingin diucapkan, namun dapat memahami secara penuh percakapan. Hal ini sesuai dengan lesi fokal pada area 44-45 (afasia Broca). CT scan kepala mendapatkan kesan atrofi otak dan multipel infark. Pasien juga pernah mengalami gejala yang diduga merupakan suatu deep vein thrombosis lebih kurang 1,5 bulan sebelum masuk rumah sakit. Oleh sebab itu kuat dugaan hal ini merupakan trombosis berulang yang dapat ditemukan pada pasien $\mathrm{PV}$.

Elliot dan Tefferi (2005) melaporkan bahwa insidensi trombosis dan perdarahan pada PV sebesar $12-39 \%$ dengan perbandingan 1:7. ${ }^{11}$ Secara umum trombosis pada PV dapat mengenai arteri atau vena, namun Landofi et al (2004) menemukan trombosis arteri jauh lebih sering dibandingkan vena. ${ }^{5}$ Najean et al (1997) mendapatkan deep vein thrombosis (DVT) dan emboli paru merupakan kasus trombosis vena tersering pada pasien PV. ${ }^{12}$ Siddiqui et al (2013) menjelaskan penatalaksanaan stroke iskemik dengan polisitemia vera adalah dengan regimen stroke bersamaan terapi PV dengan pemberian hydroxycarbamide. ${ }^{13}$ Rekomendasi stroke American Heart Association menyatakan bahwa hemodilusi dan veneseksi pada pasien stroke tidak bermanfaat kecuali pada kasus stroke dengan polisitemia vera. ${ }^{14}$ Zoraster 
et al (2013) melaporkan kasus trombosis pada PV yang menunjukkan respon yang baik dengan hemodilusi menggunakan larutan normal saline. ${ }^{15}$ Pada pasien ini juga diberikan aspirin dosis rendah yang menurut Landofli et al (2004) terbukti bermanfaat untuk mencegah trombosis pada pasien dengan polisitemia vera. ${ }^{5}$ Trombosis pada PV memiliki kecenderungan untuk berulang. Pada pasien ini terdapat episode trombosis dalam bentuk stroke 4 tahun sebelumnya dan dalam bentuk DVT 1,5 bulan sebelum perawatan. De Stefano et al (2008) melaporkan trombosis berulang pada $33,6 \%$ pasien PV dengan insidensi 7,6\% pasien tahun. ${ }^{16}$

Komorbiditas pada pasien ini berupa DM tipe 2 dan hipertensi dengan komplikasi berupa penyakit ginjal kronis. Dari anamnesis diketahui bahwa pasien telah terdiagnosis diabetes sejak 4 tahun yang lalu namun tidak terkontrol dan tidak memperoleh pengobatan yang rutin. Selain itu juga diketahui hipertensi telah diderita pasien selama 4 tahun. Ashtari et al (2012) melaporkan pasien dengan sindroma metabolik tanpa diabetes memiliki resiko 1,49 kali lebih tinggi untuk menderita stroke iskemik atau transient ischemic attack (TIA) sedangkan pasien diabetes dengan sindroma metabolik memiliki faktor resiko 2,29 kali lebih tinggi. ${ }^{17}$

Penyakit ginjal kronis (PGK) pada pasien ini didiagnosis berdasarkan abnormalitas yang ditemukan pada urinalisis dan kadar kreatinin darah yang meningkat, dikonfirmasi dengan gambaran sonogram ginjal. Tidak ada gejala yang dirasakan pasien berkaitan dengan gangguan ginjal. Tingkat klirens kreatinin pada pasien sesuai rumus Cockroft-Gault adalah $18,15 \mathrm{~mL} /$ menit sehingga menurut stratifikasi NKF-KDOQI dikategorikan sebagai PGK stage IV. ${ }^{18}$ Pencegahan progresifitas PGK terutama proteinuria pada pasien dengan diabetes dan nefropati direkomendasikan dengan ACE inhibitor dan calcium channel blocker. ${ }^{19}$ Agen antihipertensif tambahan dapat diberikan untuk mencapai target tekanan darah <140 mm Hg. ${ }^{20}$ Pada umumnya pasien yang mengalami PGK akan mengalami penurunan produksi eritrosit akibat menurunnya kadar EPO yang diproduksi ginjal. Pada pasien ini justru mengalami peningkatan eritrosit akibat peningkatan respon EPO sehingga jumlah eritrosit tetap meningkat meskipun kadar EPO sudah menurun.

Flebotomi dan pemberian aspirin dosis rendah merupakan tatalaksana utama dalam pencegahan trombosis berulang. ${ }^{21}$ Flebotomi merupakan terapi terpenting PV dimana target hematokrit $45 \%$ terbukti superior dalam mencegah trombosis berulang. ${ }^{22}$ Menurut guideline British Society for Haematology, hematokrit merupakan indikator peningkatan massa sel darah merah yang lebih baik dibanding hemoglobin, sehingga dijadikan standar dalam terapi dan pemantauan PV. ${ }^{23}$ Pemberian aspirin dosis rendah sekali sehari terbukti secara signifikan menurunkan resiko trombosis. ${ }^{5}$ Selain mencegah terjadinya trombosis, aspirin juga mengurang gejala vasomotor seperti sakit kepala dan parestesia pada penderita $\mathrm{PV} .{ }^{24}$

Berdasarkan riwayat trombosis berulang berupa stroke iskemik dan DVT, pasien ini dikategorikan resiko tinggi trombosis. Terapi yang direkomendasikan pada PV kategori resiko tinggi adalah hydroxyurea $500 \mathrm{mg}$ dua kali sehari. ${ }^{25}$ Skor Padua pasien adalah 10, dimana skor diatas 4 diindikasikan untuk diberikan profilaksis farmakologik untuk mencegah tromboemboli vena berupa heparin/enoxaparin. Pada pasien ini tidak dapat diberikan tromboprofilaksis karena klirens kreatinin <30 $\mathrm{mL} /$ menit dimana penurunan ekskresi antikoagulan akan meningkatkan resiko perdarahan. Demikian juga hydroxyurea tidak dapat diberikan karena klirens kreatinin yang rendah. ${ }^{26}$

Prognosis pada pasien ini buruk mengingat banyaknya faktor resiko untuk terjadinya trombosis berulang pada pasien ini. Resiko terjadinya trombosis European Collaboration on Low-Dose Aspirin in Polycythemia Vera (ECLAP) sebesar $4,4 \%$ pertahun sedangkan Cytoreductive Therapy in Polycythemia Vera (CYTO-PV) melaporkan 2,7\% pasien pertahun. ${ }^{27}$ Adanya sindroma metabolik pada pasien menurut Oh My et al (2014) menurunkan outcome fungsional pada pasien post-stroke. ${ }^{28}$ Dilakukan rehabilitasi medis untuk mengurangi disabilitas serta meningkatkan kemandirian pasien terutama dalam aktifitas harian. 


\section{SIMPULAN}

Terapi utama pada pasien ini seharusnya diberikan hydroxyurea, namun dikontraindikasikan karena penyakit ginjal kronis yang diderita pasien. Flebotomi dilakukan secara berkala untuk mengurangi viskositas darah dan resiko trombosis dengan target menjaga hematokrit dibawah $45 \%$.

\section{DAFTAR PUSTAKA}

1. Prenggono M. Polisitemia vera. Dalam: Sudoyo AW SB, Alwi I, Simadibrata MK, Setiati S, editor. Buku ajar ilmu penyakit dalam. Edisi ke-6. Jakarta: Penerbit Buku Kedokteran EGC; 2014.hlm. 266371.

2. Khwaja A. The role of Janus kinases in haemopoiesis and haematological malignancy. $\mathrm{Br}$ J Haematol. 2006;134(4):366-84.

3. Shier L, George T. Pathology of the myeloproliferative neoplasms. Dalam: Greer J, Arber D, Glader B, List A, Means R, Paraskevas S, editors. Wintrobe's clinical hematology. Edisi ke-13. Philadelphia: Lippincott Williams \& Wilkins; 2014.hlm.1691-93.

4. Landolfi R, Di Gennaro L. Pathophysiology of thrombosis in myeloproliferative neoplasms. Haematologica. 2011;96(2):183-6.

5. Landolfi $R$, Marchioli $R$, Kutti J, Gisslinger $H$, Tognoni G, Patrono C, et al. Efficacy and safety of low-dose aspirin in polycythemia vera. $\mathrm{N}$ Engl $\mathrm{J}$ Med. 2004;350(2):114-24.

6. Bargman JM, Skorecki K. Chronic Kidney Disease. Dalam: Fauci AS, Hauser SL, Jameson JL, Kasper DL, Longo DL, Loscalzo J, editors. Harrison's principles of internal medicine. 20 ed. New York: McGraw-Hill Education LLC; 2018.hlm.1811-25.

7. Bulucu F, Erikci S, Vural A, Caglayan S. Polycythemia vera concurrent with chronic renal failure. Nephron. 1998;80(4):486-7.

8. McMullin MF, Wilkins BS, Harrison CN. Management of polycythaemia vera: a critical review of current data. $\mathrm{Br} J$ Haematol. 2016;172(3):337-49.

9. Spivak J. Polycythemia Vera and Other Myeloproliferative Neoplasms. Dalam: Jameson JL, Kasper DL, Longo DL, Fauci AS, Hauser SL,
Loscalzo J, editor. Harrison's principles of internal medicine. 20 ed. New York: McGraw-Hill Education LLC; 2018. p. 672-4.

10. Streiff MB, Smith B, Spivak JL. The diagnosis and management of polycythemia vera in the era since the polycythemia vera study group: a survey of American Society of Hematology members' practice patterns. Blood. 2002;99(4):1144-9.

11. Elliott MA, Tefferi A. Thrombosis and haemorrhage in polycythaemia vera and essential thrombocythaemia. BJH British Journal of Haematology. 2005;128(3):275-90.

12. Najean Y, Rain JD. Treatment of Polycythemia vera: the use of hydroxyurea and pipobroman in 292 patients under the age of 65 years. Blood. 1997;90(9):3370.

13. Siddiqui MR, Mondol BA. Ischaemic Stroke as a presenting feature of polycythemia rubravera - a case report. Anwer Khan Modern Medical College Journal. 2013;4(1):45-7.

14. Adams HP, del Zoppo G, Alberts MJ, Bhatt DL, Brass L, Furlan A, et al. Guidelines for the early management of adults with ischemic stroke a guideline from the American Heart Association/American Stroke Association Stroke Council, Clinical Cardiology Council, Cardiovascular Radiology and Intervention Council, and the Atherosclerotic Peripheral Vascular Disease and Quality of Care Outcomes in Research Interdisciplinary Working Groups: The American Academy of Neurology affirms the value of this guideline as an educational tool for neurologists. Circulation. 2007;115(20).

15. Zoraster RM, Rison RA. Acute embolic cerebral ischemia as an initial presentation of polycythemia vera: a case report. Journal of Medical Case Reports. 2013;7(1).

16. De Stefano V, Za T, Rossi E, Vannucchi AM, Ruggeri M, Elli E, et al. Recurrent thrombosis in patients with polycythemia vera and essential thrombocythemia: incidence, risk factors, and effect of treatments. Haematologica Haematologica. 2008;93(3):372-80.

17. Ashtari F, Salari M, Aminoroaya A, Deljoo BK, Moeini M. Metabolic syndrome in ischemic stroke: 
A case control study. Journal of research in medical sciences. the Official Journal of Isfahan University of Medical Sciences. 2012;17(2):167-70.

18. Levey AS, Coresh J, Bolton K, Culleton B, Harvey $\mathrm{KS}$, Ikizler TA, et al. K/DOQI clinical practice guidelines for chronic kidney disease: Evaluation, classification, and stratification. American Journal of Kidney Diseases. 2002;39(2 Suppl. 1).

19. Levey AS, Rocco MV, Anderson S, Andreoli SP, Bailie GR, Bakris GL, et al. K/DOQI Clinical practice guidelines on hypertension and antihypertensive agents in chronic kidney disease. American Journal of Kidney Diseases. 2004;43(5 Suppl. 1).

20. Lerma A, Edgar V. Hypertension. Dalam: Mitchell $\mathrm{H}$, Perazella $\mathrm{M}$, editors. Current Diagnosis \& Treatment Nephrology \& hypertension. Edisi ke-2. New York: McGraw-Hill Education; 2018.hlm.13445.

21. Tefferi A, Barbui T. Essential thrombocythemia and polycythemia vera: focus on clinical practice. Mayo Clinic proceedings. 2015;90(9):1283-93.

22. Marchioli R, Cavazzina R, Marfisi RM, Masciulli A, Scarano M, Finazzi G, et al. Cardiovascular events and intensity of treatment in polycythemia vera. New England Journal of Medicine. 2013;368(1):2233.
23. A guideline for the diagnosis and management of polycythaemia vera. A British society for haematology guideline. British Journal of Haematology. 2019;184(2):176-91.

24. Tefferi A, Barbui T. Polycythemia vera and essential thrombocythemia: 2019 update on diagnosis, risk-stratification and management. Am $\mathrm{J}$ Hematol American Journal of Hematology. 2018; 94(3):156-71

25. Tefferi A, Vannucchi AM, Barbui T. Polycythemia vera treatment algorithm 2018. Blood Cancer Journal Blood Cancer Journal. 2018;8(1).

26. Hughes S, Szeki I, Nash MJ, Thachil J. Anticoagulation in chronic kidney disease patientsthe practical aspects. Clinical kidney journal. 2014;7(5):442-9.

27. Nagrale V, Olsen R, Zu Y. Updates in polycythemia vera. Dalam: Chung-Che C, Ohgami R, editors. Precision Molecular Pathology of Myeloid Neoplasms. Cham, Switzerland: Springer; 2018. hlm. 115-39.

28. Oh MY, Ko SB, Lee SH, Kim C, Ryu WS, Kim CH, et al. Association between metabolic syndrome and functional outcome in patients with acute ischaemic stroke. Eur J Neurol European Journal of Neurology. 2014;21(1):177-9. 